\title{
Corynebacterium humireducens sp. nov., an alkaliphilic, humic acid-reducing bacterium isolated from a microbial fuel cell
}

Correspondence

Fang-Bai Li

cefbli@soil.gd.cn

Shun-Gui Zhou

sgzhou@soil.gd.cn
Chun-Yuan Wu, ${ }^{1,2}$ Li Zhuang, ${ }^{1}$ Shun-Gui Zhou, ${ }^{1}$ Fang-Bai Li ${ }^{1}$ and Jian $\mathrm{He}^{3}$

\author{
${ }^{1}$ Guangdong Institute of Eco-Environmental and Soil Sciences, Guangzhou 510650, PR China \\ ${ }^{2}$ Guangzhou Institute of Geochemistry, Chinese Academy of Sciences, Guangzhou 510640, PR \\ China \\ ${ }^{3}$ Key Laboratory for Microbiological Engineering of the Agricultural Environment, Ministry of \\ Agriculture, Nanjing Agricultural University, Nanjing 210095, PR China
}

Microbe-mediated humic substance reduction has been widely recognized, and quinone moieties have been shown to be the redox-active compounds in humic substances (Lovley et al., 1996; Scott et al., 1998; Straub et al., 2005). Humic substance reduction may play a significant role in the anaerobic biotransformation of both organic and inorganic compounds. A wide variety of organic compounds, including priority pollutants, can be mineralized by micro-organisms under anaerobic conditions with humic substances serving as the terminal electron acceptor (Bradley et al., 1998; Cervantes et al., 2000, 2001; Finneran \& Lovley, 2001). In addition, humic substances, once reduced, can shuttle electrons to insoluble electron acceptors (e.g. ferric oxides) and several distinct contaminants (e.g. azo dyes, chlorinated organic contaminants) by acting as a redox mediator (Bond \& Lovley, 2002; Kappler et al., 2004; Hong et al., 2007; Wang et al., 2009). Wang et al. (2009) found that the reduction rate of 2,4dichlorophenoxyacetic acid (2,4-D) was increased signific-

Abbreviations: $\mathrm{AH}_{2} \mathrm{DS}$, reduced anthraquinone-2,6-disulphonate; AODS, anthraquinone-2,6-disulphonate.

The GenBank/EMBL/DDBJ accession number for the 16S rRNA gene sequence of strain MFC-5 $5^{\top}$ is GQ421281.

Three supplementary figures are available with the online version of this paper. antly by the addition of quinone, which was reduced microbially to the corresponding hydroquinone, which could then reduce $2,4-\mathrm{D}$ chemically.

A large number of humic acid-reducing micro-organisms have been isolated from a broad range of environments (Field \& Cervantes, 2005) and the humic acid reductions mediated by these micro-organisms are commonly studied at circumneutral $\mathrm{pH}$. To the best of our knowledge, no studies have reported humic acid reduction under alkaline conditions or by an alkaliphilic humic acid-reducing bacterium. In this study, we successfully isolated a new alkaliphilic bacterium, strain MFC-5 ${ }^{\mathrm{T}}$, from an alkaline microbial fuel cell and identified its ability to reduce humic acids (quinone) under alkaline conditions.

Strain MFC- $5^{\mathrm{T}}$ was isolated from the anode of a wastewater-fed microbial fuel cell in our laboratory that was continuously operated at $\mathrm{pH}$ 10.0. A piece of anode $\left(0.5 \mathrm{~cm}^{3}\right)$ was transferred to a $25.2 \mathrm{ml}$ sterile bottle containing $20 \mathrm{ml}$ sterilized mineral salts medium [MSM, containing (per litre deionized water) $0.6 \mathrm{~g} \mathrm{NaH} \mathrm{PO}_{4}$, $0.25 \mathrm{~g} \mathrm{NH}_{4} \mathrm{Cl}, 0.1 \mathrm{~g} \mathrm{KCl}, 0.2 \mathrm{~g}$ yeast extract, $10.0 \mathrm{ml}$ vitamin stock solution and $10.0 \mathrm{ml}$ mineral stock solution (Zachara et al., 1998); pH 10.0] supplemented with $0.5 \mathrm{mM}$ anthraquinone-2,6-disulphonate (AQDS; electron acceptor), $5 \mathrm{mM}$ sodium lactate (electron donor) and 
$10 \mathrm{mM}$ carbonate buffer. The bottle was purged with $\mathrm{O}_{2}$ free $\mathrm{N}_{2} / \mathrm{CO}_{2}(80: 20, \mathrm{v} / \mathrm{v})$ for 15 min and sealed with a butyl-rubber stopper and an aluminium cap. After 10 days of incubation, the colour of the contents of the bottle changed to red and the enriched population was serially diluted and plated onto MSM agar ( $\mathrm{pH} 10.0)$ supplemented with $\left(1^{-1}\right) 18 \mathrm{~g}$ agar, $1 \mathrm{mmol}$ AQDS and $5 \mathrm{mmol}$ sodium lactate. The plates were incubated in an anaerobic chamber (ShelLab; Sheldon Manufacturing) with $\mathrm{N}_{2} / \mathrm{CO}_{2}$ $(80: 20, \mathrm{v} / \mathrm{v})$. Strain MFC- $5^{\mathrm{T}}$ formed red colonies owing to its ability to reduce AQDS.

To identify morphological features, strain $\mathrm{MFC}-5^{\mathrm{T}}$ was cultivated aerobically on LB agar overnight at $30^{\circ} \mathrm{C}$. Cell morphology and dimensions were determined by scanning electron microscopy (ESEM-30; Philips). Cell motility was tested by the hanging-drop method. Physiological characteristics were determined by standard methods (Buchanan \& Gibbons, 1974). Salt tolerance was determined in MSM supplemented with $0.5 \mathrm{mM}$ AQDS and $5 \mathrm{mM}$ sodium lactate and on LB agar supplemented with $0-15 \%(\mathrm{w} / \mathrm{v}) \mathrm{NaCl}$. The isolate was characterized biochemically using the API Coryne and API ZYM systems (bioMérieux), according to the manufacturer's instructions. Cellular fatty acids were extracted from dried cells and methylated and analysed as described by Kämpfer \& Kroppenstedt (1996). Extraction of genomic DNA was performed according to Chun \& Goodfellow (1995). The
$\mathrm{G}+\mathrm{C}$ content of the DNA was determined by HPLC as described by Mesbah et al. (1989).

The 16S rRNA gene of the isolate was amplified by PCR using conserved primers that bind close to the $3^{\prime}$ and $5^{\prime}$ ends of the gene, as described by Finneran et al. (2003). The purified PCR product was sequenced using an automated sequencer (ABI 3730; Applied Biosystems). The sequence was aligned with related 16S rRNA gene sequences from GenBank (http://blast.ncbi.nlm.nih.gov/Blast.cgi) and the Ribosomal Database Project (http://rdp.cme.msu.edu/ seqmatch) using CLUSTAL $\mathrm{x}$ (Thompson et al., 1997) and gaps at the $5^{\prime}$ and $3^{\prime}$ ends were removed. Phylogenetic trees were constructed with MEGA version 4.0 using the maximum-parsimony and neighbour-joining methods (Kumar et al., 2004) according to Kimura's two-parameter model and bootstrap analyses were based on 1000 resamplings (Kimura, 1980; Saitou \& Nei, 1987). 16S rRNA gene sequence similarities between strain MFC- $5^{\mathrm{T}}$ and its closest known relatives were calculated using the EzTaxon server.

To investigate AQDS reduction by strain MFC- $5^{\mathrm{T}}$, batch experiments were conducted in a $25.2 \mathrm{ml}$ serum bottle using cells grown aerobically in LB medium to lateexponential phase, harvested by centrifugation $(8000 \mathrm{~g}$ at $4{ }^{\circ} \mathrm{C}$ for $10 \mathrm{~min}$ ), washed twice and resuspended in sterilized MSM. To determine the $\mathrm{pH}$ range for AQDS reduction, $20 \mathrm{ml}$ MSM (containing $1 \times 10^{7}$ cells $\mathrm{ml}^{-1}$,

Table 1. Characteristics that can be used to differentiate strain MFC-5 ${ }^{\top}$ from alkaliphilic and halotolerant corynebacteria

Strains: 1, Corynebacterium humireducens sp. nov. MFC-5 ${ }^{\mathrm{T}} ; 2$, C. halotolerans YIM $70093^{\mathrm{T}}$ (data from Chen et al., 2004); 3, C. marinum D7015 ${ }^{\mathrm{T}}$ (Du et al., 2010); 4, C. maris Coryn $-1^{\mathrm{T}}$ (Ben-Dov et al., 2009); 5, C. matruchotii ( $n=6$; Barrett et al., 2001); 6, C. testudinoris $\mathrm{M} 935 / 96 / 4^{\mathrm{T}}$ (Collins et al., 2001); 7, C. urealyticum ( $n=6$; Pitcher et al., 1992). All strains were negative for aesculin hydrolysis, $\beta$-galactosidase and $N$-acetyl- $\beta$-glucosaminidase (no data available for C. urealyticum) and acid production from mannitol, xylose and lactose. ND, No data available.

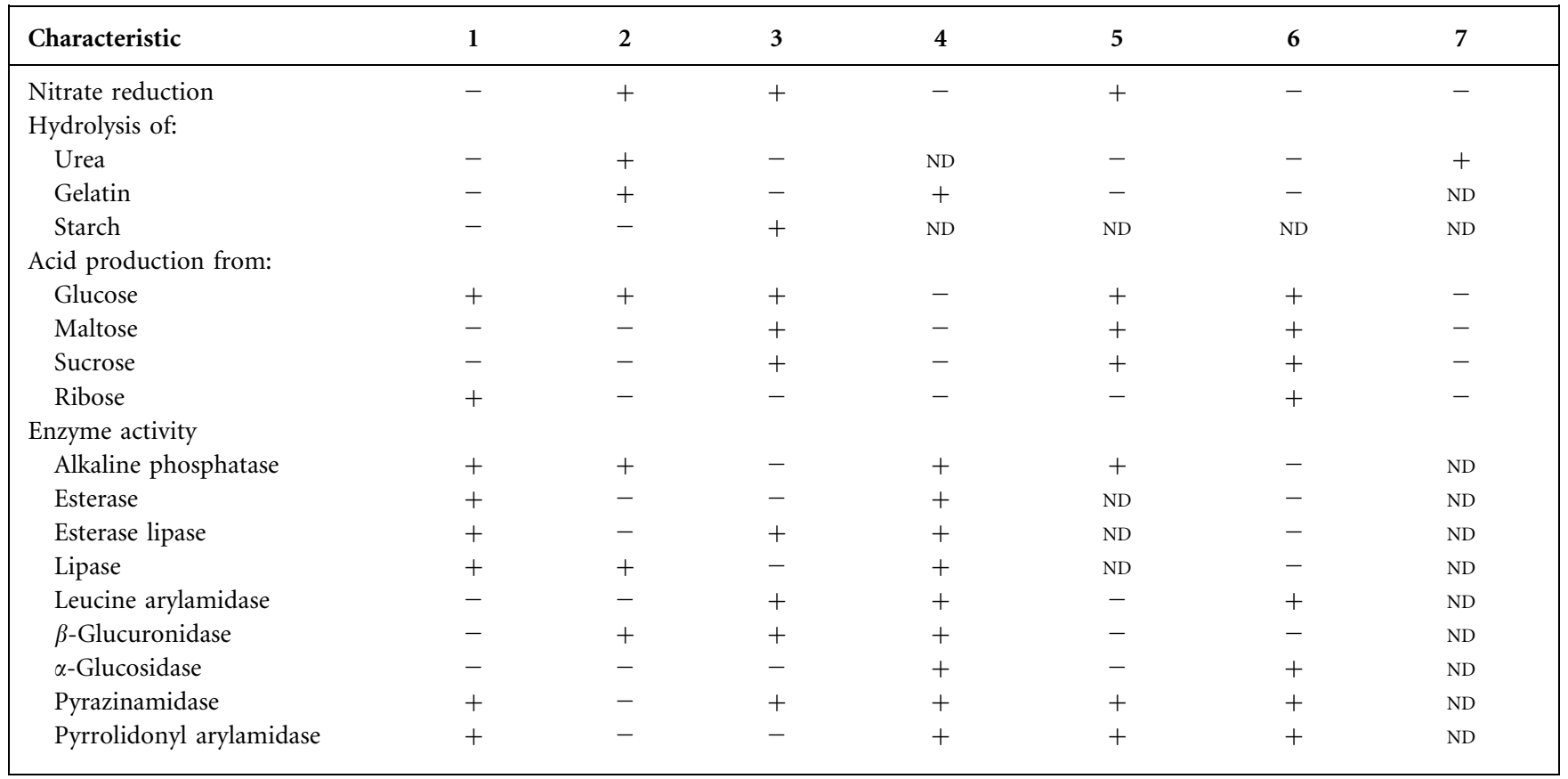


$5 \mathrm{mM}$ lactate and $1 \mathrm{mM}$ AQDS) was adjusted to $\mathrm{pH} 6.0$ 11.0 (at intervals of $1 \mathrm{pH}$ unit). The $\mathrm{pH}$ was maintained using $20 \mathrm{mM}$ phosphate buffer (for $\mathrm{pH}$ 6.0-8.0) (Pham et al., 2003) or carbonate buffer ( $\mathrm{pH}$ 9.0-11.0) (Ye et al., 2004). To determine alternative electron donors for AQDS reduction, each bottle contained $1 \times 10^{7}$ cells $\mathrm{ml}^{-1}, 20 \mathrm{ml}$ MSM with $1 \mathrm{mM}$ AQDS and one of the following substrates $(5 \mathrm{mM})$ : formate, acetate, propionate, lactate, citrate, ethanol, glycerol and sucrose. For the treatment using lactate, cell numbers were determined by direct colony counts on LB agar. Strict anaerobic and sterile techniques were used throughout the reduction experiments, as described by Li et al. (2009). All treatments were tested in triplicate in the dark at $30{ }^{\circ} \mathrm{C}$ with two control assays: an abiotic set without cells and a biotic set without electron donor or acceptor. To determine the quantities of reduced AQDS $\left(\mathrm{AH}_{2} \mathrm{DS}\right)$, triplicate bottles were sacrificed every 2 days, the samples were filter-sterilized (PVDF, $0.22 \mu \mathrm{m}$; Millipore) and $\mathrm{AH}_{2} \mathrm{DS}$ was quantified using a UV-Vis spectrophotometer (TU1800-PC; PGeneral) at a wavelength of $408 \mathrm{~nm}$ (Liu et al., 2007).

Vegetative cells of strain MFC- $5^{\mathrm{T}}$ were straight to curved rods, $1.0-2.0 \mu \mathrm{m}$ long and $0.5-0.7 \mu \mathrm{m}$ wide (Supplementary Fig. S1, available in IJSEM Online). Cells occurred singly or in pairs, were non-motile and stained Grampositive during exponential and stationary growth. After $24 \mathrm{~h}$ on LB agar, colonies were uniformly round, 0.5$1.0 \mathrm{~mm}$ in diameter, yellowish, dry and rough with a distinct wrinkled morphology.

The temperature for growth of strain MFC- $5^{\mathrm{T}}$ was $25-$ $40{ }^{\circ} \mathrm{C}$ (optimum $37{ }^{\circ} \mathrm{C}$ ); no growth was observed at 45 or below $10{ }^{\circ} \mathrm{C}$. Growth was observed at $\mathrm{pH} 7.0-11.0$ (optimum $\mathrm{pH}$ 9.0) and with $0-12 \% \mathrm{NaCl}$, but not with $13 \% \mathrm{NaCl}$. The isolate was catalase-positive and oxidaseand methyl red-negative. With the API systems, strain MFC $-5^{\mathrm{T}}$ produced acid from glucose and ribose, but not from maltose, sucrose, mannose, xylose or lactose, and was positive for alkaline phosphatase, esterase, esterase lipase, lipase, pyrazinamidase and pyrrolidonyl arylamidase, but not for leucine arylamidase, $N$-acetyl- $\beta$-glucosaminidase, $\beta$-glucuronidase or $\beta$-galactosidase. In terms of overall phenotypic characteristics, the isolate resembled corynebacteria. Comparing the biochemical characteristics of strain MFC $-5^{\mathrm{T}}$ with representatives of alkaliphilic and halotolerant species of the genus Corynebacterium (Table 1) suggested that the isolate represented a novel species of the genus Corynebacterium.

Fig. 1(a) shows the reduction of AQDS by strain MFC- $5^{\mathrm{T}}$ using lactate as the electron donor at different $\mathrm{pH}$. After 10 days, the $\mathrm{AH}_{2} \mathrm{DS}$ concentration at $\mathrm{pH} 7,8,9,10$ and 11 was $0.23,0.14,0.48,0.31$ and $0.16 \mathrm{mM}$, respectively. Reduction of AQDS at pH 6.0 was negligible. In the abiotic control, $<0.07 \mathrm{mM} \mathrm{AH}_{2} \mathrm{DS}$ was formed (data not shown). Thus, the $\mathrm{pH}$ range for AQDS reduction by strain MFC $-5^{\mathrm{T}}$ was $\mathrm{pH} 7.0-11.0$ and the optimum $\mathrm{pH}$ was $\mathrm{pH}$ 9.0. To the best of our knowledge, the reduction of humic acids and quinone by alkaliphilic bacteria has not been reported, and the identification of strain MFC- $5^{\mathrm{T}}$ raises the upper $\mathrm{pH}$ limit for microbial quinone reduction. As shown in Fig. 1(b), $\mathrm{AH}_{2} \mathrm{DS}$ was produced with formate, acetate, lactate, ethanol and sucrose as electron donors, but not with citrate, propionate or glycerol (not shown). The electron donors could be ranked according to the final concentration of $\mathrm{AH}_{2} \mathrm{DS}$, in descending order, as sucrose, acetate, lactate, ethanol and formate. In the abiotic control, almost no $\mathrm{AH}_{2} \mathrm{DS}$ was detected (not shown). As shown in Fig. $1(c)$, significant microbial growth and AQDS reduction were observed with lactate as the electron donor over 10 days. Cell density in the active test approached a maximum of $13.7 \times 10^{7}$ cells $\mathrm{ml}^{-1}$, which was approximately 14 times greater than the initial density. Data showed that AQDS reduction and the increase in cell numbers occurred at the same time throughout the

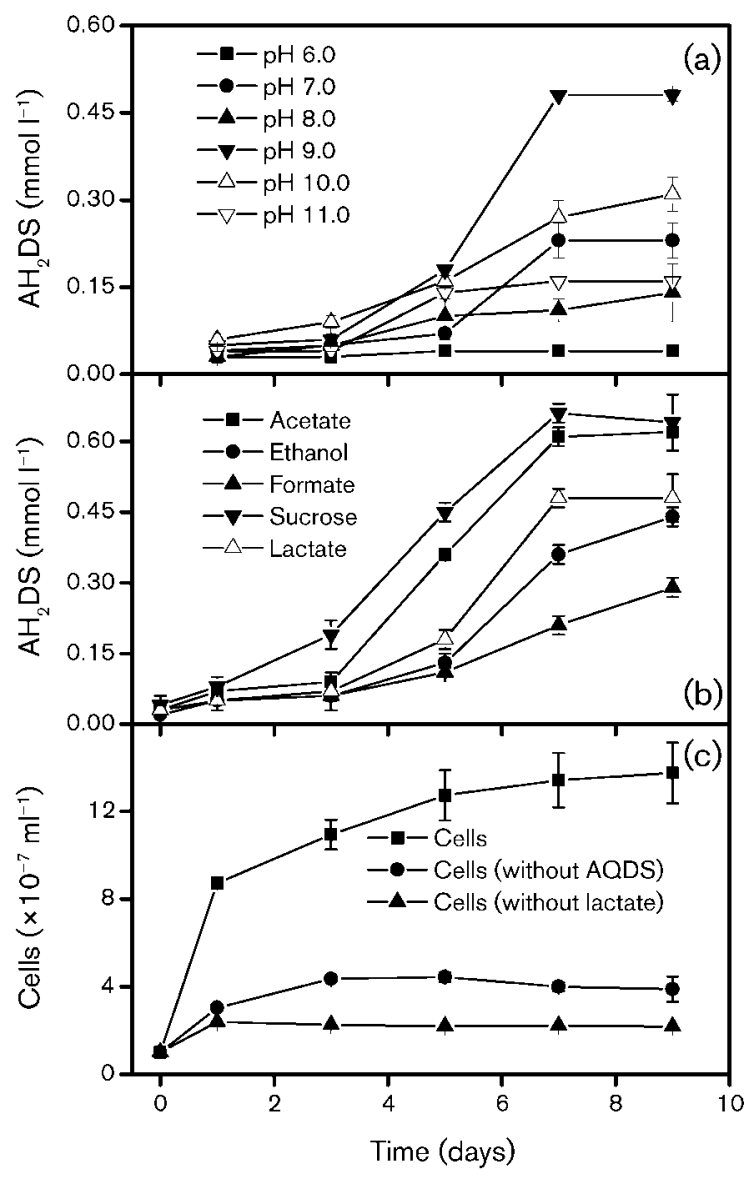

Fig. 1. Characteristics of AQDS reduction by strain MFC $-5^{\top}$ over 10 days. (a) Production of $\mathrm{AH}_{2} \mathrm{DS}$ with lactate as electron donor at $\mathrm{pH}$ 6.0-11.0. (b) Production of $\mathrm{AH}_{2} \mathrm{DS}$ with various electron donors $\left(5 \mathrm{mM} \mathrm{I}^{-1}\right)$ at $\mathrm{pH}$ 9.0. (c) Cell growth with AQDS and lactate as electron donor at $\mathrm{pH}$ 9.0. Experiments were performed in MSM medium under anaerobic conditions at $30{ }^{\circ} \mathrm{C}$ with $1 \times 10^{7}$ cells $\mathrm{ml}^{-1}$ initial cell density. Error bars represent standard deviations $(n=3)$. 


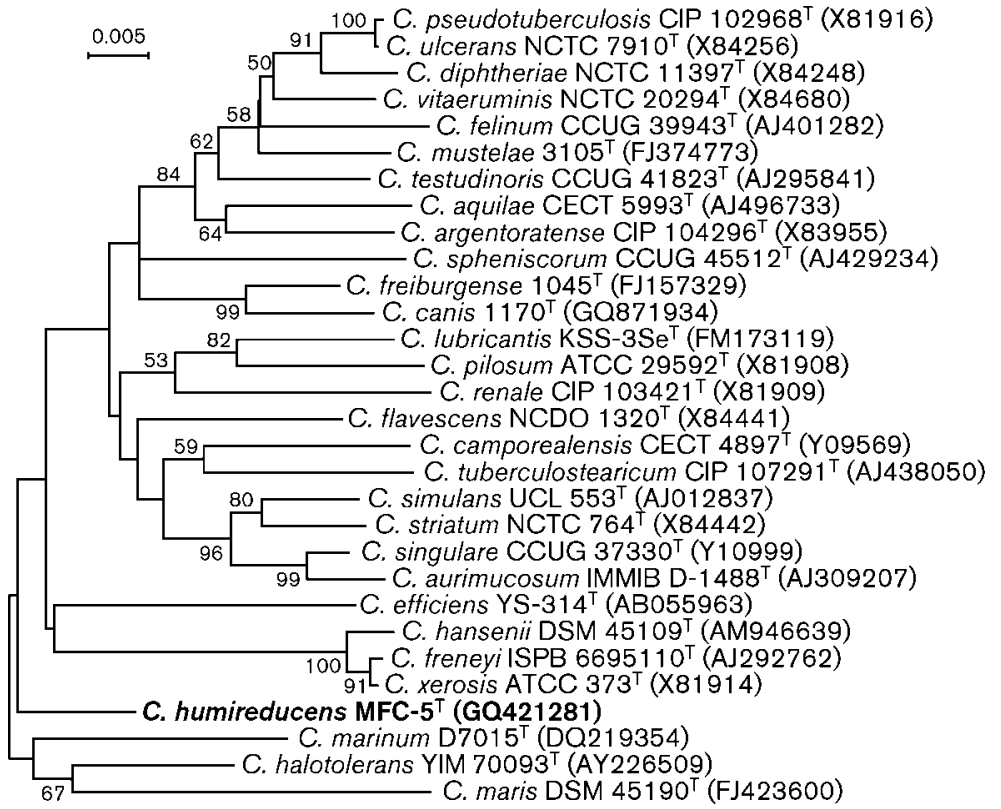

Fig. 2. Neighbour-joining phylogenetic tree based on 16S rRNA gene sequences, showing the position of strain MFC- $5^{\top}$ among its phylogenetic neighbours. Bootstrap values $(>50 \%)$ based on 1000 resamplings are shown at branch nodes. Bar, $0.5 \%$ sequence divergence. incubation. Cell growth was negligible in controls without AQDS or lactate, which indicated that strain MFC- $5^{\mathrm{T}}$ could not ferment lactate and only grew in the presence of both AQDS and lactate. As far as is known, this is the first report of a member of the genus Corynebacterium that can reduce extracellular quinones and harness energy for microbial growth by quinone reduction.

Examination of the long-chain cellular fatty acids of strain MFC- $-5^{\mathrm{T}}$ showed that the non-hydroxylated long-chain cellular fatty acids were primarily straight-chain saturated and mono-unsaturated. The major acids were $\mathrm{C}_{14: 0}$ $(1.55 \%), C_{16: 0}(33.69 \%), C_{17: 0}(3.39 \%), C_{18: 0}(7.56 \%)$, $\mathrm{C}_{17: 1} \omega 8 c(5.14 \%), \mathrm{C}_{18: 1} \omega 9 c(42.68 \%)$ and $\mathrm{C}_{18: 1} \omega 7 c$ $(1.71 \%)$, which were consistent with the genus Corynebacterium (Fernández-Garayzábal et al., 2004). The DNA G + C content of strain MFC $-5^{\mathrm{T}}$ was $59.0 \mathrm{~mol} \%$, which fell within the range for the genus Corynebacterium (52.0-68.0 mol\%). The presence of straight-chain saturated and mono-unsaturated fatty acids and the $\mathrm{G}+\mathrm{C}$ content, along with the morphological and biochemical properties, strongly suggested that strain MFC- $5^{\mathrm{T}}$ was a member of the genus Corynebacterium.

A nearly complete $16 \mathrm{~S}$ rRNA gene sequence (1401 nt) was obtained for strain MFC- $5^{\mathrm{T}}$. The closest known relatives of strain MFC- $5^{\mathrm{T}}$ were Corynebacterium marinum D7015 (96.9\% 16S rRNA gene sequence similarity, $1393 \mathrm{bp}$ considered), C. testudinoris CCUG $41823^{\mathrm{T}} \quad(96.8 \%$, $1395 \mathrm{bp})$, C. halotolerans YIM $70093^{\mathrm{T}}(96.4 \%, 1392 \mathrm{bp})$, C. felinum CCUG $39943^{\mathrm{T}}(96.0 \%, 1383 \mathrm{bp})$, C. singulare CCUG $37330^{\mathrm{T}}(96.0 \%, 1297 \mathrm{bp})$ and C. freiburgense $1045^{\mathrm{T}}$ $(95.9 \%, 1395 \mathrm{bp})$. A sequence alignment was created with sequences from the type strains of 98 species of the genus Corynebacterium and the results of phylogenetic analysis are shown in Supplementary Fig. S2. The neighbour-joining and maximum-parsimony trees depicting the phylogenetic relationships between strain MFC- $5^{\mathrm{T}}$ and its nearest phylogenetic neighbours (95.3-96.9\% 16S rRNA gene sequence similarity) are shown in Fig. 2 and Supplementary Fig. S3, respectively. The results suggested that strain MFC $-5^{\mathrm{T}}$ belongs to the genus Corynebacterium.

It is widely accepted that $\geqslant 3 \% 16 \mathrm{~S}$ rRNA gene sequence divergence between bacterial strains indicates that they represent different genomic species (Stackebrandt \& Goebel, 1994). Therefore, on the basis of phenotypic, genotypic and phylogenetic properties, strain MFC $-5^{\mathrm{T}}$ should be classified in a novel species of the genus Corynebacterium, for which the name Corynebacterium humireducens sp. nov. is proposed.

\section{Description of Corynebacterium humireducens sp. nov.}

Corynebacterium humireducens [hu.mi.re.du'cens. L. n. humus soil, used to refer to humic substances; L. part. adj. reducens leading back (to a reduced oxidation state); N.L. part. adj. humireducens converting humic substances to a reduced oxidation state].

Cells are Gram-positive-staining, non-motile, facultatively anaerobic, straight to curved rods $(1.0-2.0 \mu \mathrm{m}$ long and $0.5-0.7 \mu \mathrm{m}$ wide). Colonies on LB agar are uniformly round, $0.5-1.0 \mathrm{~mm}$ in diameter, yellowish, dry and rough, with a distinct wrinkled morphology after $24 \mathrm{~h}$. Optimum growth occurs at $37{ }^{\circ} \mathrm{C}$, at $\mathrm{pH} 9.0$ and with $10 \% \mathrm{NaCl}$ (aerobic conditions). Positive for catalase but negative for oxidase, urease, reduction of nitrate and hydrolysis of urea, gelatin and tyrosine. Produces acid from glucose and ribose, but not from arabinose, fructose, galactose, lactose, maltose, mannitol, mannose, raffinose, rhamnose, salicin, sucrose, trehalose or xylose. Positive for alkaline phospha- 
tase, esterase, esterase lipase, lipase, pyrazinamidase and pyrrolidonyl arylamidase, but not for leucine arylamidase, $N$-acetyl- $\beta$-glucosaminidase, $\beta$-glucuronidase or $\beta$-galactosidase. Grows with AQDS as the sole terminal electron acceptor at $\mathrm{pH}$ 7.0-11.0 (optimum $\mathrm{pH}$ 9.0) under anaerobic conditions. Available electron donors include formate, acetate, ethanol, lactate and sucrose, but not propionate, glycerol or citrate. The major cellular fatty acids $(>5 \%)$ are $\mathrm{C}_{18: 1} \omega 9 c, \mathrm{C}_{16: 0}, \mathrm{C}_{18: 0}, \mathrm{C}_{17: 1} \omega 8 c$ and $\mathrm{C}_{17: 0}$. The DNA $\mathrm{G}+\mathrm{C}$ content of the type strain is $59.0 \mathrm{~mol} \%$.

The type strain, MFC $-5^{\mathrm{T}}\left(=\mathrm{NBRC} 106098^{\mathrm{T}}=\mathrm{CGMCC}\right.$ $2452^{\mathrm{T}}=$ DSM $45392^{\mathrm{T}}$ ), was isolated from a microbial fuel cell fed with artificial wastewater and operated continuously at $\mathrm{pH} 10.0$.

\section{Acknowledgements}

This research was supported by the National Natural Science Foundations of China (grant no. 40801119), the Guangdong Natural Science Foundation (grant no. 8151065003000005) and the International Foundation for Science (grant nos AC/20137 and C/ 18074).

\section{References}

Barrett, S. L., Cookson, B. T., Carlson, L. C., Bernard, K. A. \& Coyle, M. B. (2001). Diversity within reference strains of Corynebacterium matruchotii includes Corynebacterium durum and a novel organism. J Clin Microbiol 39, 943-948.

Ben-Dov, E., Ben Yosef, D. Z., Pavlov, V. \& Kushmaro, A. (2009). Corynebacterium maris sp. nov., a marine bacterium isolated from the mucus of the coral Fungia granulosa. Int J Syst Evol Microbiol 59, 2458-2463.

Bond, D. R. \& Lovley, D. R. (2002). Reduction of Fe(III) oxide by methanogens in the presence and absence of extracellular quinones. Environ Microbiol 4, 115-124.

Bradley, P. M., Chapelle, F. H. \& Lovley, D. R. (1998). Humic acids as electron acceptors for anaerobic microbial oxidation of vinyl chloride and dichloroethene. Appl Environ Microbiol 64, 3102-3105.

Buchanan, R. E. \& Gibbons, N. E. (editors) (1974). Bergey's Manual of Determinative Bacteriology, 8th edn. Baltimore: Williams \& Wilkins.

Cervantes, F. J., van der Velde, S., Lettinga, G. \& Field, J. A. (2000). Quinones as terminal electron acceptors for anaerobic microbial oxidation of phenolic compounds. Biodegradation 11, 313-321.

Cervantes, F. J., Dijksma, W., Duong-Dac, T., Ivanova, A., Lettinga, G. \& Field, J. A. (2001). Anaerobic mineralization of toluene by enriched sediments with quinones and humus as terminal electron acceptors. Appl Environ Microbiol 67, 4471-4478.

Chen, H.-H., Li, W.-J., Tang, S.-K., Kroppenstedt, R. M., Stackebrandt, E., $\mathrm{Xu}$, L.-H. \& Jiang, C.-L. (2004). Corynebacterium halotolerans sp. nov., isolated from saline soil in the west of China. Int J Syst Evol Microbiol 54, 779-782.

Chun, J. \& Goodfellow, M. (1995). A phylogenetic analysis of the genus Nocardia with $16 \mathrm{~S}$ rRNA gene sequences. Int J Syst Bacteriol 45, 240-245.

Collins, M. D., Hoyles, L., Hutson, R. A., Foster, G. \& Falsen, E. (2001). Corynebacterium testudinoris sp. nov., from a tortoise, and Corynebacterium felinum sp. nov., from a Scottish wild cat. Int J Syst Evol Microbiol 51, 1349-1352.
Du, Z.-J., Jordan, E. M., Rooney, A. P., Chen, G.-J. \& Austin, B. (2010). Corynebacterium marinum sp. nov. isolated from coastal sediment. Int J Syst Evol Microbiol 60, 1944-1947.

Fernández-Garayzábal, J. F., Vela, A. I., Egido, R., Hutson, R. A., Lanzarot, M. P., Fernández-García, M. \& Collins, M. D. (2004). Corynebacterium ciconiae sp. nov., isolated from the trachea of black storks (Ciconia nigra). Int J Syst Evol Microbiol 54, 2191-2195.

Field, J. A. \& Cervantes, F. J. (2005). Microbial redox reactions mediated by humus and structurally related quinones. In Use of Humic Substances to Remediate Polluted Environments: from Theory to Practice, pp. 343-352. Edited by I. V. Perminova, K. Hatfield \& N. Hertkorn. Dordrecht: Springer.

Finneran, K. T. \& Lovley, D. R. (2001). Anaerobic degradation of methyl tert-butyl ether (MTBE) and tert-butyl alcohol (TBA). Environ Sci Technol 35, 1785-1790.

Finneran, K. T., Johnsen, C. V. \& Lovley, D. R. (2003). Rhodoferax ferrireducens sp. nov., a psychrotolerant, facultatively anaerobic bacterium that oxidizes acetate with the reduction of Fe(III). Int $J$ Syst Evol Microbiol 53, 669-673.

Hong, Y. G., Guo, J., Xu, Z. C., Xu, M. Y. \& Sun, G. P. (2007). Humic substances act as electron acceptor and redox mediator for microbial dissimilatory azoreduction by Shewanella decolorationis S12. J Microbiol Biotechnol 17, 428-437.

Kämpfer, P. \& Kroppenstedt, R. M. (1996). Numerical analysis of fatty acid patterns of coryneform bacteria and related taxa. Can J Microbiol 42, 989-1005.

Kappler, A., Benz, M., Schink, B. \& Brune, A. (2004). Electron shuttling via humic acids in microbial iron(III) reduction in a freshwater sediment. FEMS Microbiol Ecol 47, 85-92.

Kimura, M. (1980). A simple method for estimating evolutionary rates of base substitutions through comparative studies of nucleotide sequences. J Mol Evol 16, 111-120.

Kumar, S., Tamura, K. \& Nei, M. (2004). MEGA3: integrated software for molecular evolutionary genetics analysis and sequence alignment. Brief Bioinform 5, 150-163.

Li, X. M., Zhou, S. G., Li, F. B., Wu, C. Y., Zhuang, L., Xu, W. \& Liu, L. (2009). $\mathrm{Fe}$ (III) oxide reduction and carbon tetrachloride dechlorination by a newly isolated Klebsiella pneumoniae strain L17. J Appl Microbiol 106, 130-139.

Liu, C. X., Zachara, J. M., Foster, N. S. \& Strickland, J. (2007). Kinetics of reductive dissolution of hematite by bioreduced anthraquinone2,6-disulfonate. Environ Sci Technol 41, 7730-7735.

Lovley, D. R., Coates, J. D., Blunt-Harris, E. L., Phillips, F. J. P. \& Woodward, J. C. (1996). Humic substances as electron acceptors for microbial respiration. Nature 382, 445-448.

Mesbah, M., Premachandran, U. \& Whitman, B. (1989). Precise measurement of the $\mathrm{G}+\mathrm{C}$ content of deoxyribonucleic acid by highperformance liquid chromatography. Int J Syst Bacteriol 39, 159-167.

Pham, C. A., Jung, S. J., Phung, N. T., Lee, J., Chang, I. S., Kim, B. H., Yi, H. \& Chun, J. (2003). A novel electrochemically active and Fe(III)reducing bacterium phylogenetically related to Aeromonas hydrophila, isolated from a microbial fuel cell. FEMS Microbiol Lett 223, 129-134.

Pitcher, D., Soto, A., Soriano, F. \& Valero-Guillén, P. (1992). Classification of coryneform bacteria associated with human urinary tract infection (group D2) as Corynebacterium urealyticum sp. nov. Int $J$ Syst Bacteriol 42, 178-181.

Saitou, N. \& Nei, M. (1987). The neighbor-joining method: a new method for reconstructing phylogenetic trees. Mol Biol Evol 4, 406425.

Scott, D. T., Mcknight, D. M., Blunt-Harris, E. L., Kolesar, S. E. \& Lovley, D. R. (1998). Quinone moieties act as electron acceptors in the 
reduction of humic substances by humics-reducing microorganisms. Environ Sci Technol 32, 2984-2989.

Stackebrandt, E. \& Goebel, B. M. (1994). Taxonomic note: a place for DNA-DNA reassociation and $16 \mathrm{~S}$ rRNA sequence analysis in the present species definition in bacteriology. Int J Syst Bacteriol 44, 846-849.

Straub, K. L., Kappler, A. \& Schink, B. (2005). Enrichment and isolation of ferric-iron- and humic-acid-reducing bacteria. Methods Enzymol 397, 58-77.

Thompson, J. D., Gibson, T. J., Plewniak, F., Jeanmougin, F. \& Higgins, D. G. (1997). The CLUSTAL_X windows interface: flexible strategies for multiple sequence alignment aided by quality analysis tools. Nucleic Acids Res 25, 4876-4882.
Wang, Y. B., Wu, C. Y., Wang, X. J. \& Zhou, S. G. (2009). The role of humic substances in the anaerobic reductive dechlorination of 2,4dichlorophenoxyacetic acid by Comamonas koreensis strain CY01. J Hazard Mater 164, 941-947.

Ye, Q., Roh, Y., Carroll, S. L., Blair, B., Zhou, J., Zhang, C. L. \& Fields, M. W. (2004). Alkaline anaerobic respiration: isolation and characterization of a novel alkaliphilic and metal-reducing bacterium. Appl Environ Microbiol 70, 5595-5602.

Zachara, J. M., Fredrickson, J. K., Li, S. M., Kennedy, D. W., Smith, S. C. \& Gassman, P. L. (1998). Bacterial reduction of crystalline $\mathrm{Fe}^{3+}$ oxides in single phase suspensions and subsurface materials. Am Mineral 83, 1426-1443. 